\title{
Optimalisasi Layanan Bimbingan Kelompok untuk Meningkatkan Kebiasaan Siswa Bertanya dalam Proses Pembelajaran di SMK Negeri 4 Gowa
}

\author{
H. Burhanuddin \\ SMK Negeri 4 Gowa, Kabupaten Gowa Provinsi Sulawesi Selatan \\ Corresponding Author. Email: burhanuddin@gmail.com
}

\begin{abstract}
The purpose of this study is to improve the habit of asking students in the learning process through the optimization of group guidance services. This research method uses classroom action research. The research procedure consists of planning, acting, observing and reflecting in 3 cycles. The subjects of this study were 10 students of class XI TKJ2 SMK Negeri 4 Gowa. The research data collection technique used observation and questionnaires. While the data analysis in this study used a qualitative descriptive. The results of this study indicate that there is an increase in the habits of students in asking through the optimization of group guidance services. The increase in the habit of asking can be seen from the results of observations during the action process in group guidance activities, namely the existence of demands to display questioning behavior, the form of questioning behavior that is displayed is spontaneous, can choose the right time to ask and ask well without offending other people's feelings. As supporting data, to determine the increase in the habit of asking questions is through observations made by counseling teachers and subject teachers as a comparison. The result of the class is that there is an increase in the habit of asking in the learning process gradually from cycles 1,2 and 3 . In cycle 1 the frequency of asking questions is $40 \%$, cycle II is $60 \%$ and in cycle III there is $80 \%$. Thus through the optimization of group guidance services can increase the activeness of asking group members in the learning process.
\end{abstract}

\begin{abstract}
Abstrak: Tujuan penelitian ini adalah untuk meningkatkan kebiasaan bertanya siswa dalam proses pembelajaran melalui optimalisasi layanan bimbingan kelompok. Metode penelitian ini menggunakan penelitian tindakan kelas. Adapun prosedur penelitian ini terdiri perencanaan, tindakan, pengamatan dan refleksi yang dilakukan dalam 3 siklus. Subyek penelitian ini adalah siswa kelas XI TKJ2 SMK Negeri 4 Gowa sebanyak 10 orang siswa. Teknik pengumpulan data penelitian ini menggunakan pengamatan dan angket. Sedangkan analisis data dalam penelitian ini menggunakan deskriptif kualitatif. Hasil penelitian ini menunjukkan bahwa terdapat peningkatan kebiasaan siswa dalam bertanya melalui optimalisasi layanan bimbingan kelompok. Peningkatan kebiasaan bertanya dapat dilihat dari hasil observasi selama proses tindakan dalam kegiatan bimbingan kelompok yaitu adanya tuntutan untuk menampilkan tingkah laku bertanya, bentuk tingkah laku bertanya yang ditampilkan bersifat pontan, dapat memilih saat yang tepat untuk bertanya dan bertanya dengan baik tanpa menyinggung perasan orang lain. Sebagai data pendukung untuk mengetahui peningkatan kebiasaan bertanya adalah melalui observasi yang dilakukan oleh guru BK dan guru mata pelajaran sebagai pembanding. Hasilnya kelas yaitu ada peningkatan kebiasaan bertanya dalam proses pembelajaran secara bertahap dari siklus 1,2 dan 3. Pada siklus 1 frekuensi bertanya $40 \%$, siklus II $60 \%$ dan pada siklus III ada $80 \%$. Dengan demikian melalui optimalisasi layanan bmbingan kelmpok dapat meningkatkan keaktifan bertanya anggota kelompok dalam proses pembelajaran.
\end{abstract}

Article History

Received: 12-12-2020

Revised: 02-01-2021

Published: 07-01-2021

Key Words:

Group Guidance, Habit of Asking.

\section{Sejarah Artikel}

Diterima: 12-12-2020

Direvisi: 02-01-2021

Diterbitkan: 07-01-2021

\section{Kata Kunci:}

Bimbingan kelompok, Kebiasaan Bertanya.

How to Cite: Burhanuddin, H. (2021). Optimalisasi Layanan Bimbingan Kelompok untuk Meningkatkan Kebiasaan Siswa Bertanya dalam Proses Pembelajaran di SMK Negeri 4 Gowa. Jurnal Paedagogy, 8(1). doi:https://doi.org/10.33394/jp.v8i1.3238 


\section{Pendahuluan}

Pendidikan merupakan kebutuhan manusia yang sangat penting karena pendidikan mempunyai tugas untuk menyiapkan SDM bagi pembangunan bangsa dan negara. Kemajuan ilmu pengetahuan dan teknologi (IPTEK) mengakibatkan perubahan dan pertumbuhan kearah yang lebih kompleks. Hal ini menimbulkan masalah-masalah sosial dan tuntutan-tuntutan baru yang tidak dapat diramalkan sebelumnya, sehingga pendidikan selalu menghadapi masalah karena adanya kesenjangan antara yang diharapkan dengan hasil yang dapat dicapai dari proses pendidikan (Gunawan, et al, 2020; Zultoni. \& Astuti, 2020).

Pendidikan pada dasarnya merupakan proses untuk membantu manusia dalam mengembangkan potensi dirinya sehingga mampu menghadapi setiap perubahan yang terjadi. Tetapi proses pendidikan ini banyak yang mengatakannya sebagai proses belajar- mengajar, yang kemudian mempengaruhi jiwa pendidik sehingga yang dilakukannya adalah mengajarkan ilmu pengetahuan saja. Apa yang sering terjadi adalah hanya proses menstransfer ilmu pengetahuan kepada anak didik, soal pembentukan karakter dan moral tidak diutamakan (Sulistiya \& Jumailiyah, 2020; Gunawan \& Wulandari, 2017).

Salah satu prinsip Kurikulum Berbasis Kompetensi (KBK) adalah kegiatan belajar mengajar lebih berpusat pada siswa, keaktifan siswa menjadi dasar keberhasilan proses belajar mengajar. Bahkan siswa dituntut lebih banyak belajar mandiri di luar kelas. Guru sebagai fasilitator dalam kegiatan belajar mengajar lebih banyak memotivasi dan mengarahkan siswa untuk mencapai kompetensi yang diharapkan. Keaktifan siswa di dalam KBK dapat digambarkan seperti mendengarkan dan memahami materi yang disampaikan guru, membuat catatan tentang hal-hal penting yang dibahas dalam pelajaran, merespon situasi yang berkembang dalam proses pembelajaran: bertanya tentang hal-hal yang belum dipahami, menjawab pertanyaan guru dan mengomentari secara positif apa yang dikemukakan temannya.

Hasil pengalaman dan pengamatan peneliti, banyak ditemukan siswa yang memiliki kebiasaan bertanya rendah di dalam proses pembelajaran khususnya di SMK Negeri 4 Gowa. Hal ini ditunjukan dari banyaknya siswa yang hanya diam mendengarkan penjelasan guru, rendahnya kebiasaan siswa untuk bertanya mempunyai kecenderungan karena siswa tidak memiliki pertanyaan, malu bertanya, takut bertanya, tidak bisa menyusun kalimat untuk bertanya, atau memiliki alasan lain sehingga tidak mau bertanya. Sikap siswa yang demikian itu menyebabkan guru sering mengeluh, guru menjadi kurang bersemangat dalam mengajar dan proses pembelajaran kurang mencapai hasil yang maksimal.

Dengan mengoptimalkan kegiatan layanan bimbingan kelompok dan menggunakan topik tugas, topik bebas dan campuran topik bebas dan tugas sesuai dengan permasalahan yang dikemukakan siswa sebagai anggota kelompok, maka anggota kelompok berlatih mengemukakan pendapat dan berlatih bertanya. Adapun tujuan penelitian ini adalah untuk meningkatkan kebiasaan bertanya siswa di dalam proses pembelajaran melalui optimalisasi layanan bimbingan kelompok di SMK Negeri 4 Gowa.

\section{Metode Penelitian}

Metode penelitian ini menggunakan penelitian tindakan kelas. Adapun prosedur penelitian ini terdiri perencanaan, tindakan, pengamatan dan refleksi yang dilakukan dalam 3 siklus, masing-masing siklus dilaksanakan dengan topik yang berbeda, siklus 1 menggunakan topik bebas, siklus 2 menggunakan topik tugas, dan siklus 3 menggunakan topik campuran yaitu topik bebas dan tugas. Subyek penelitian ini adalah siswa kelas XI TKJ 2 SMK Negeri 4 Gowa sebanyak 10 orang siswa. Teknik pengumpulan data penelitian ini menggunakan 
pengamatan dan angket. Adapun teknik analisis data yang dpergunakan dalam penelitian ini adalah teknik deskriftif kualitatif dengan prosesntase. Selanjutnya dari hasil analisis tersebut dideskripsikan dalam tindakan: (1) ada tidaknya peningkatan kualitas kebiasaan bertanya siswa dalam layanan bimbingan kelompok; (2) ada tidaknya peningkatan kuantitas siswa dalam bertanya ketika bimbingan kelompOk; dan (3) ada tidaknya kuantitas bertanya ketika pelajaran Bahasa Indonesia. Secara garis besar analisis data yang dilakukan dalam penelitian ini dengan langkah-langkah prosedur yang diambil adalah Pengolahan dan telaah data.

\section{Hasil Penelitian dan Pembahasan Deskripsi Siklus 1 \\ Pelaksanaan Tindakan Siklus}

Tindakan siklus 1 dilaksanakan sesuai dengan jadwal yang telah direncanakan. Tempat kegiatan bimbingan kelompok dilaksanakan di ruang Bimbingan Konseling, pelaksana tindakan adalah peneliti sekaligus sebagai guru pembimbing dan pemimpin kelompok. Secara garis besar kegiatan bimbingan kelompok berlangsung dalam tahap-tahap yaitu tahap I pembentukan, tahap II peralihan, tahap III kegiatan dan tahap IV pengakhiran. Adapun uraian setiap tahapan adalah sebagai berikut;

Tahap I, pada tahap ini kelompok yang terdiri dari 10 (sepuluh) orang, duduk dalam bentuk lingkaran. Adapun tujuan pembentukan kelompok dalam bentuk lingkaran ini sambil menjelaskan pengertian pengertian, maksud dan tujuan Bimbingan kelompok adalah: (1) Anggota memahami, pengertian dan tujuan bimbingan kelompok, (2) tumbuh minat anggota mengikuti kegiatan bimbingan kelompok, (3) tumbuh suasana kelompok yang menyenangkan, (4) Tumbuhnya saling mengenal, percaya, menerima dan membantu diantara para anggota, (5) tumbuhnya suasana bebas dan terbuka.

Tugas peneliti (pemimpin kelompok) pada tahap I ini adalah; (1) mengungkapkan pengertian dan tujuan kelompok; (2) menjelaskan cara-cara dan asas-asas; (3) saling memperkenalkan diri dan mengungkapkan diri. Sedangkan hal-hal penting yang dilakukan pemimpin kelompok adalah menampilkan diri secara utuh dan terbuka dan menampilkan penghormatan kepada orang lain, hangat, tulus, bersedia membantu dan empati

Tahap II, pada tahap ini sebagai pemimpin kelompok, berusaha memberi penjelasan tentang kegiatan bahwa tahap I sudah berakhir dan sekarang akan dilanjutkan dengan tahap II yaitu tahap peralihan. Tujuan tahap ini antara lain; (1) terbebasnya anggota dari perasaan atau sikap enggan, ragu atau saling tidak percaya untuk memasuki tahap berikutnya; (2) memantapkan suasana kelompok dan kebersamaannya; (3) memantapkan minat untuk ikut seta dalam kegiatan kelompok. Inti kegiatan tahap II adalah; (1) menjelaskan kegiatan yang akan ditempuh pada tahap berikutnya; (2) menawarkan dan mengamati apakah para anggota sudah siap menjalani kegiatan pada tahap berikutnya; (3) membahas susana yang terjadi dan meningkatkan keikutsertaan anggota.

Tahap III, pada saat ini pemimpin kelompok berusaha mengajak anggota kelompok utuk mengemukakan masalah yang dialami atau yang mengganggu perasaan peserta, sesuai dengan topik yang bahas adalah topik bebas. Tujuan yang ingin dicapai pada tahap ini adalah; (1) terungkapnya masalah yang dirasakan, dipikirkan dan yang dialami oleh anggota; (2) Terbahasnya masalah dan topik yang dikemukakan secara mendalam dan tuntas; (3) ikut sertanya seluruh anggota secara aktif, dinamis dalam membahas masalah, baik ysng menyangkut tingkah laku, pemikiran atau perasaan.

Inti kegiatan pada tahap III ini meliputi; (1) masing-masing anggota mengemukakan masalah; (2) menetapkan masalah; (3) anggota membahs secara mendalam dan tuntas dan 
kegiatan selingan. Peranan pemimpin kelompok dalam tahap ini hanya sebagai pengatur lalu lintas, aktif tapi tidak banyak bicara, karena yang dituntut banyak bicara adalah para anggota kelompok.

Tahap IV Pengakhiran, Pokok perhatian lebih ditujukan pada hasil yang telah dicapai oleh kelompok, kegiatan kelompok dipusatkan pada pembahasan dan penjelajahan tentang apakah para anggota akan mampu menerapkan komitmen yang telah mereka sepakati. Disamping itu, yang juga penting adalah pada akhir kegiatan ini anggota kelompok benarbenar telah memetik suatu hasil yang berharga dari kegiatan kelompok yang diikutinya.

Tujuan yang ingin dicapai pada tahap pengakhiran ini adalah; (1) Terungkapnya kesan-kesan para anggota kelompok; (2) terungkapnya hasil kegiatan kelompok yang telah dicapai; (3) terumuskannya rencana kegiatan kelompok lebih lanjut. Peranan pemimpin kelompok pada kegiatan pengakhiran ini adalah tetap mengusahakan suasana hangat, bebas dan terbuka, memberikan pernyataan dan mengucapkan terimakasih pada seluruh anggota serta memeberikan dorongan pada seluruh anggota untuk mengikuti kegiatan selanjutnya. Hasil pelaksanaan tindakan siklus 1 yang ditujukan kelompok ini dapat dilihat pada resume pelaksanaan bimbingan kelompok sebagai berikut:

\section{Pengamatan Tindakan}

Proses tahap demi tahap bimbingan kelompok berjalan dengan lancar, namun pada awal tahap pembentukan anggota kelompok nampak masih ragu-ragu mengikuti kegiatan bimbingan kelompok dan masih malu menmperkenalkan dirinya. Pada tahap II peralihan, sebagian besar anggota menunjukan sikap sukarela, namun ada sebanyak 3 orang anggota dalam kelompok yang nampak kurang menunjukan sikap sukarela, hal ini ditunjukan dari sikapnya kurang melibatkan diri dalam kelompok. Pada tahap III yaitu tahap kegiatan ini, merupakan tahap yang dapat mengukur bagaimana sikap anggota dalam mengemukakan pendapatnya dalam membahas suatu masalah. Masing-masing siswa secara bergantian mengemukakan pendapatnya, namun tidak semua anggota membahas dengan jelas dan terperinci.

Diakhir kegiatan atau tahap pengakhiran, sebagian anggota memberikan kesan-kean yang positif dan sebagian lagi belum memberikan komentarnya. Sedangkan observasi terhadap kebiasaan bertanya siswa dapat diketahui dari masih rendahnya tuntutan untuk menampilkan tingkah laku bertanya, bentuk tingkah laku bertanya yang dimunculkan masih rendah, ketepatan situasi saat bertanya masih belum tepat, cara bertanya dalam kategori cukup dan peningkatan kebiasaan bertanya masih kurang.

Berdasarkan observasi yang dilakukan dalam proses layanan informasi sebagai data penunjang yang dilakukan sebanyak 2 kali pertemuan, ternyata siswa yang sangat sering bertanya masih $0 \%$ yang paling tinggi adalah dalam kategori cukup $40 \%$ sedangkan yang tidak pernah bertanya ada $10 \%$.

Tabel 1. Refleksi Siklus Pertama

\begin{tabular}{|c|c|c|}
\hline Tindakan yang dicobakan & Deskripsi keberhasilan & Deskripsi kegagalan \\
\hline $\begin{array}{l}\text { Bimbingan } \\
\text { dengan topik bebas dan } \\
\text { menggunakan permainan : } \\
\text { tigas dot, pertanya mengapa } \\
\text { dan karena, untuk melatih } \\
\text { siswa mengemuakan } \\
\text { pendapat }\end{array}$ & $\begin{array}{l}\text { Rasa percaya diri dan sikap } \\
\text { sukarela dalam mengikuti } \\
\text { kegiatan sebagian besar } \\
\text { sudah ada. } \\
\text { Frekuensi bertanya atau } \\
\text { mengemukakan pendapat } \\
\text { dalam kategori cukup } 40 \%\end{array}$ & $\begin{array}{l}\text { Hampir } 50 \% \text { siswa masih } \\
\text { diam didalam proses } \\
\text { pembelajaran. } \\
\text { Hambatan dalam kegiatan } \\
\text { bimbingan kelompok: } \\
\text { Waktu pelaksanaan hanya } \\
\text { dibatasi } 80 \quad \text { menit, }\end{array}$ \\
\hline
\end{tabular}




\begin{tabular}{|c|c|c|}
\hline $\begin{array}{l}\text { mengungkapkan sesuatu } \\
\text { yang dipikirkannya }\end{array}$ & $\begin{array}{l}\text { sedangkan yang tidak } \\
\text { pernah bertanya ada } 10 \% \text {. } \\
\text { Di lihat dari motif bertanya } \\
\text { prosentasi tertinggi adalah } \\
\text { direncanakan atau disiapkan } \\
\text { lebih dahulu sebanyak } 35 \% \text {, } \\
\text { dihumbau oleh guru } \\
\text { sebanyak } 30 \% \text {. Hal ini } \\
\text { menunjukan bahwa secara } \\
\text { umum kebiasaan bertanya } \\
\text { dalam proses pembelajaran } \\
\text { masih harus dikembangkan. }\end{array}$ & $\begin{array}{l}\text { seyogyanya dapat } \\
\text { diperpanjang sesuai dengan } \\
\text { kebutuhan. } \\
\text { Sebagian besar anggota } \\
\text { kelompok memiliki karakter } \\
\text { pendiam, pemalu dan } \\
\text { rendah diri sehinga } \\
\text { memerlukan waktu yang } \\
\text { cukup lama dalam melatih } \\
\text { dan membiasakan ke arah } \\
\text { yang lebih positif. } \\
\text { Kegiatan pengamatan } \\
\text { dalam proses pembelajaran } \\
\text { terhambat oleh waktu yang } \\
\text { terbatas karena jarak antara } \\
\text { pelaksanaan tindakan dan } \\
\text { observasi cukup dekat. } \\
\text { Disamping itu program } \\
\text { pengajaran guru sering } \\
\text { tidak sesuai dengan } \\
\text { pedoman observasi yang } \\
\text { telah dibuat. }\end{array}$ \\
\hline
\end{tabular}

Dengan ditemukan berbagai hal tersebut di atas, maka dicari solusi untuk kegiatan bimbingan kelompok siklus 2 sebagai berikut :

1) Pemimpin kelompok atau guru pembimbing memperjelas tujuan dan manfaat bimbingan kelompok agar anggota kelompok lebih antusias mengikuti kegiatan kelompok.

2) Memperjelas dan menanamkan pentingnya meningkatkan keaktifan di dalam di dalam proses pembelajaran.

3) Memperjelas keterkaitan mamfatat keaktifan di dalam kelas dengan prestasi dan keberhasilan kelulusan yang akan datang.

4) Mengganti bentuk permainan yang lebih menarik untuk meningkatkan semangat para anggota.

5) Pada tahap kegiatan awal, anggota diarahkan untuk berbagi pengalaman untuk memperlancar komuniksi para anggota.

\section{Deskripsi Siklus 2}

Revisi tindakan siklus 2 dilakukan berdasarkan kelemahan /kekurangan yang ditemukan pada siklus 1 .

Tabel 2 . Rencana Tindakan Siklus Kedua

\begin{tabular}{c|c|c|c}
\hline $\begin{array}{c}\text { Tujuan yang ingin } \\
\text { dicapai }\end{array}$ & $\begin{array}{c}\text { Tindakan yang } \\
\text { dicobakan }\end{array}$ & Jenis permainan & $\begin{array}{c}\text { Kegiatan } \\
\text { Bimbingan }\end{array}$ \\
\hline
\end{tabular}




\begin{tabular}{|c|c|c|c|}
\hline $\begin{array}{lr}\text { Meningkatkan } & \\
\text { keterlibatan } & \text { anggota } \\
\text { kelompok } & \text { dan } \\
\text { menambah } & \text { suasana } \\
\text { keakraban } & \text { antar } \\
\text { anggota } & \end{array}$ & $\begin{array}{l}\text { Bimbingan } \\
\text { kelompok dengan } \\
\text { topik Tugas : (1) } \\
\text { Pada tahap } \\
\text { pembentukan } \\
\text { dimulai, pemimpin } \\
\text { kelompok } \\
\text { menjelaskan kembali } \\
\text { tujuan dan mamfaat } \\
\text { bimbingan kelompok } \\
\text { dan menanamkan } \\
\text { pentingnya } \\
\text { meningkatkan } \\
\text { keaktifan dalam } \\
\text { proses pembelajaran, } \\
\text { (2) pemimpin } \\
\text { kelompok } \\
\text { memperjelas } \\
\text { keterkaitan antara } \\
\text { keaktifan siswa di } \\
\text { kelas dengan prestasi } \\
\text { dan keberhasilan } \\
\text { dalam ujian yang } \\
\text { akan datang. }\end{array}$ & $\begin{array}{lr}\text { Bernyanyi } & \\
\text { bersama, } & \\
\text { permainan } & \\
\text { "Perasaan } & \text { dan } \\
\text { tanggapan", } & \text { dan } \\
\text { "pertanyaan } & - \\
\text { jawaban } & \end{array}$ & $\begin{array}{l}\text { Meliputi tahap- } \\
\text { tahap } \\
\text { bimbingan } \\
\text { kelompok: } \\
\text { Tahap } \\
\text { pembentukan } \\
\text { Tahap } \\
\text { peralihan } \\
\text { Tahap kegiatan } \\
\text { Tahap penutup }\end{array}$ \\
\hline
\end{tabular}

\section{Pelaksanaan Tindakan}

Tempat kegiatan bimbingan kelompok dilaksanakan di tempat shalat. Tahapantahapan yang dilalui dalam bimbingan kelompok siklus 2 ini hampir sama dengan kegiatan siklus 1, pada tahap pembentukan siswa atau anggota kelompok nampak terbiasa dengan situasi bimbingan kelompok. Pertama-tama pemimpin kelompok mengajak siswa untuk berdo'a terlebih dahulu, kemudian pemimpin kelompok menjelaskan kembali tujuan, manfaat dan azas-azas bimbingan kelompok dan menjelaskan hal-hal yang telah tercantum dalam refleksi 1.

Tahap berikutnya adalah peralihan, anggota kelompok memperhatikan dengan seksama penjelasan pemimpin kelompok tentang topik tugas yang akan dibahas, kemudian mereka bertanya tentang contoh topik tugas tersebut. Pada tahap ini nampak sudah siap memasuki tahap berikutnya, walaupun ada 1-2 anggota yang kurang bersemangat. Pemimpin kelompok mengajak anggota kelompok bernyanyi bersama untuk menciptakan suasanan yang lebih hidup dan memberikan suatu pertanyaan yang ditulis pada selembar kertas yang disediakan pemimpin kelompok. Pertanyaannya seperti "Bagaimana suasana hari ini ?", dan " Apa yang kamu pikirkan saat ini ?", jawaban anggota kelompok tersebut dapat menjadi bahan masukan bagi pemimpin kelompok untuk mengetahui apa yang sedang dipikirkan anggota kelompok. Sebagian besar jawabn dari pertanyaan 1 adalah sangat menyenangkan dan jawaban kedua cukup bervariasi.

Memasuki tahap III yaitu kegiatan, anggota kelompok cukup antusias mendengarkan topik bahasan yang dikemukakan pemimpin kelompok. Adapun topik yang dibahas adalah " Meningkatkan kebiasaan bertanyaan dalam proses pembelajaran", pemimpin kelompok juga 
menjelaskan pentingnya topik tersebut dibahas dalam kelompok. Anggota kelompok mengadakan tanya jawab terhadap topik yang dibahas diantaranya adalah Bagaimana menumbuhkan kebiasaan bertanya, apa penyebab atau latar belakang siswa di dalam kelas tidak mau bertanya, bagaimana pemahaman siswa apabila rajin bertanya dengan guru, dan sebagainya.

Berdasarkan gambaran keaktifan anggota kelompok tersebut dapat diketahui bahwa anggota kelompok dapat berkomunikasi dengan lancar, namun ada 1-2 orang pula yang lebih banyak diam . Untuk mengatasi hal itu pemimpin kelompok mengadakan permainan pesan berantai. Diakhir tahap kegiatan ini pemimpin kelompok menegaskan komitmen para anggota yaitu; (1) menghilangkan rasa malu; (2) Latihan bertanya dimuka cermin; (3) Menyiapkan pertanyaan sebelum pertanyaan dimulai; (4) meningkatkan kosentrasi sehingga muncul rasa ingin tahu lebih jauh tentang materi yang bahas oleh guru.

Pada tahap pengakhiran, seperti halnya siklus 1 anggota kelompok mengemukakan kesan yang menilai kemajuan yang dicapai masing-masing dan juga membahas kegiatan yang akan dilaksanakan selanjutnya. Kemudian kegiatan bimbingan kelompok diakhiri dengan pembacaan do'a. Setelah selesai kegiatan bimbingan kelompok ini, pemimpin kelompok mengisi pedoman observasi proses tindakan siklus 2 yang nantinya dievaluasi pada pembahasan hasil penelitian.

\section{Refleksi}

Pelaksanaan bimbingan kelompok siklus 2 yang telah dilakukan menunjukan keberhasilan yang lebih meningkat dibandingkan dengan siklus 1. Adapun hasil yang dicapai tertera di dalam tabel berikut.

\section{Tabel 3. Refleksi Siklus Kedua}

\begin{tabular}{|c|c|c|}
\hline Tindakan yang dicobakan & Deskripsi keberhasilan & Deskripsi kegagalan \\
\hline $\begin{array}{l}\text { Bimbingan kelompok } \\
\text { dengan topik tugas dan } \\
\text { menggunakan permainan : } \\
\text { perasaan dan tanggapan, } \\
\text { pertanyaan dan jawaban dan } \\
\text { pesan berantai }\end{array}$ & $\begin{array}{l}\text { (1) pengidentifikasian topik } \\
\text { yang dibahas memenuhi } \\
\text { kebutuhan } \\
\text { kelompok, anggota } \\
\text { Pengkomunikasian rencana } \\
\text { layanan terlaksana dengan } \\
\text { baik dan dipahami oleh } \\
\text { guru dan siswa, (3) } \\
\text { Penyelengaraan layanan } \\
\text { bimbingan kelompok } \\
\text { melalui } \\
\text { pelaksaaannya; tahap-tahap } \\
\text { pembentukan, peralihan, } \\
\text { kegiatan dan pengakhiran } \\
\text { dilaksanakan secara teratur } \\
\text { mengikuti prosedur yang } \\
\text { ada, (4) sikap dan minat } \\
\text { anggota kelompok terhadap } \\
\text { kegiatan layanan lebih baik } \\
\text { dilihat dari aspek } \\
\text { pemahaman terhadap } \\
\text { layanan bimbingan }\end{array}$ & $\begin{array}{l}\text { Aspek perencanaan yang } \\
\text { menjadi titik kelemahan } \\
\text { adalah kurangnya fasilitas } \\
\text { layanan yang terkait dengan } \\
\text { tempat atau ruang yang } \\
\text { belum memenuhi syarat, (2) } \\
\text { menetapkan materi evaluasi } \\
\text { dan menyusun istrumentasi } \\
\text { evaluasi yang bersifat tidak } \\
\text { terencana dengan baik } \\
\text { sehingga evaluasi kurang } \\
\text { optimal. } \\
\text { Masih ada siswa yang } \\
\text { cenderung kurang percaya } \\
\text { diri untuk bertanya. }\end{array}$ \\
\hline
\end{tabular}




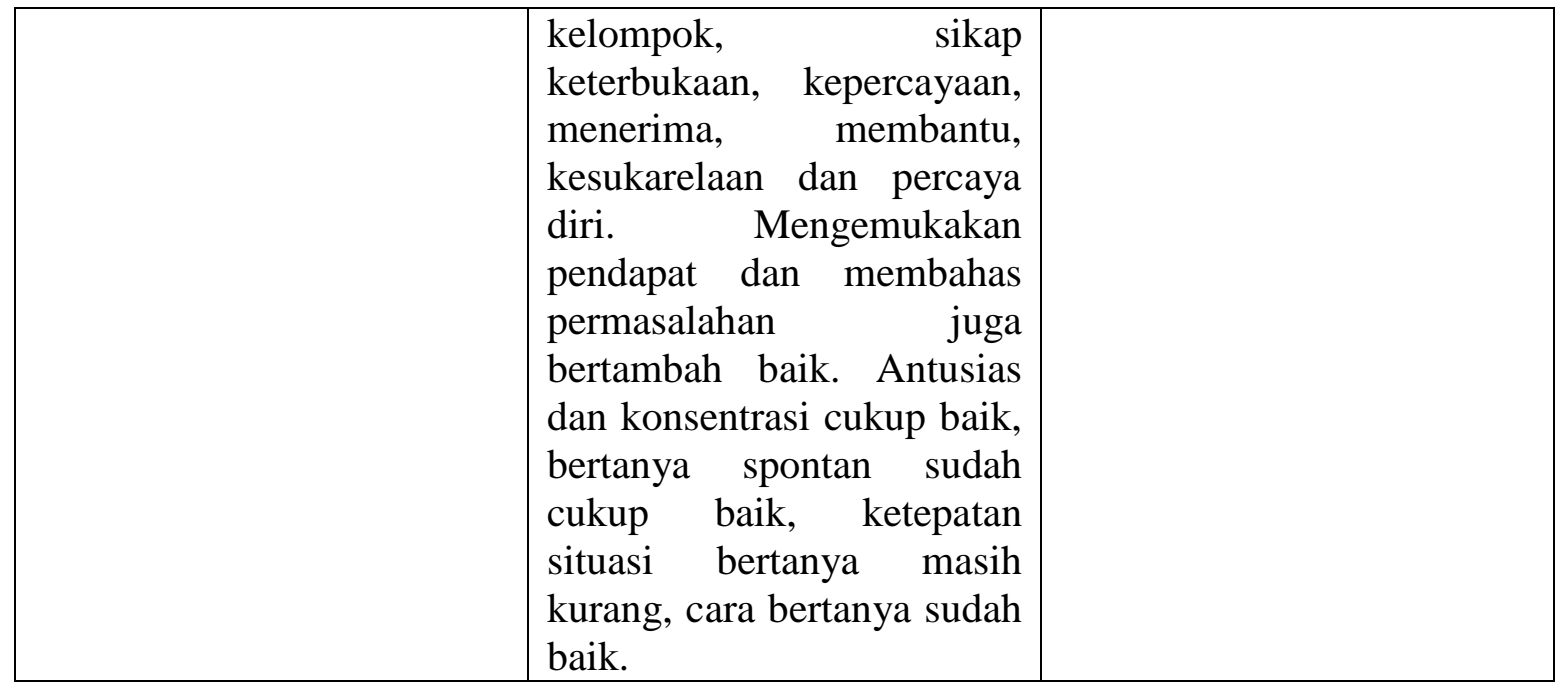

\section{Pelaksanaan Tindakan}

Kegiatan bimbingan kelompok dilaksanakan oleh peneliti sekaligus sebagai guru pembimbing/pemimpin kelompok. Secara garis besar kegiatan bimbingan kelompok dilaksanakan dalam empat tahap . Pada tahap I pembentukan pemimpin kelompok mengajak untuk membaca doa terlebih dahulu, kemudian menjelaskan secara singkat kegiatan bimbingan kelompok III dan menjelaskan jenis topik yang akan dibahas. Pada tahap II peralihan, pemimpin kelompok hanya menanyakan kesiapan anggota kelompok untuk memasuki tahap III, hal ini dilakukan karena suasana kelompok telah menunjukan kebersamaan berminat mengikuti kegiatan layanan.

Tahap ketiga yaitu tahap kegiatan, pemimpin kelompok menjelaskan topik yang pertama kali dibahas, yaitu topik tugas, topiknya; "Menumbuhkan semangat dalam mengikuti proses pembelajaran". Topik yang kedua adalah topik bebas, topik ini muncul berdasarkan pembahasan dari topik tugas. Pembahasan kedua topik ini dilakukan bertujuan agar perkembangan topik yang dibahas dapat dengan leluasa dicari jalan keluarnya dan tentunya untuk kepentingan anggota kelompok.

Tujuan pertama dalam kegiatan III ini adalah terbahasnya topik yang ditugaskan secara mendalam dan tugas dan tujuan kedua adalah terungkapnya secara bebas topik yang dirasakan, dipikirkan atau dialami oleh anggota kelompok. Sedangkan tugas anggota kelompok adalah aktif bertanya jawab antara anggota kelompok dan mengemukkan pendapatnya masing-masing, pemimpin kelompok berperan sebagai pengatur lalu lintas, aktif tetapi tidak banyak bicara. Tahap IV adalah pengakhiran, tahap bertujuan terungkapnya kesan-kesan anggota kelompok dan terungkapnya hasil kegiatan kelompok yang telah dicapai.

\section{Kesimpulan}

Kesimpulan yang diperoleh dari hasil penelitian ini adalah dengan mengoptimalkan layanan bimbingan kelompok dapat meningkatkan kebiasaan siswa bertanya di dalam proses pembelajaran. Berdasarkan hasil observasi pada proses pelaksanaan layanan bimbingan kelompok, menunjukkan ada peningkatan keterlibatan siswa mengikuti layanan bimbingan kelompok di lihat dari aspek pemahaman baru, perasaan positif, rencana kegiatan dan sikap yang antusias, sehingga dapat diamati peningkatan kebiasan bertanya siswa selama mengikuti tindakan dari siklus 1, 2, dan 3 semakin meningkat. Peningkatan tuntutan untuk menampilkan 
tingkah laku bertanya, pertanyaan diajukan secara spontan, memperhatikan situasi yang dihadapi untuk bertanya, memperhatikan cara bertanya yang sesuai dengan nilai-nilai kepatutan. Pelaksanaan bimbingan kelompok yang optimal terbukti meningkatkan kebiasaan bertanya siswa. Hasil observasi guru pembimbing kepada anggota kelompok ketika mengikuti layanan informasi dan atau layanan penguasaan konten membuktikan sebagai berikut: pada siklus pertama pertanyaan atau komentar yang muncul dari siswa anggota kelompok sebanyak 40\%. Sedangkan pada siklus ke dua ada 60\% dari siswa anggota kelompok. Dan terdapat $80 \%$ pertanyaan atau komentar dari siswa anggota kelompok dalam layanan informasi setelah bimbingan kelompok siklus ke tiga. Dengan demikian jika dibandingkan dengan layanan pasca siklus ke dua maka terdapat 20\% kenaikan, dan $40 \%$ kenaikan dari layanan pasca siklus pertama. Jadi dengan demikian terbukti bahwa dengan adanya pelaksanaan layanan bimbingan kelompok dapat meningkatkan keberanian dan keaktifan bertanya siswa anggota kelompok dalam mengikuti layanan informasi dan layanan penguasaan konten yang diadakan guru BK. Sedangkan data pendukung dari guru mata pelajaran berdasarkan hasil wawancara menunjukkan ada peningkatan keberanian bertanya dari 10 siswa anggota kelompok dalam mengikuti proses pembelajaran.

\section{Saran}

Adapun saran yang disampaikan berdasarkan hasil penelitian ini adalah agar guru untuk terus konsisten menerapkan layanan bimbingan kelompok ini agar kemampuan bertanya siswa semakin meningkat. Selain itu diharapkan penerapan layanan bimbingan kelompok ini juga dapat digunakan untuk mata pelajaran lainnya.

\section{Daftar Pustaka}

Fattah, Nanang. (2003). Landasa Manajemen Pendidikan. Bandung : PT Remaja Rosda Karya.

Gunawan, I., Hartati, A., \& Mulachela, F. (2020). Pengaruh Konseling Kelompok Terhadap Perilaku Agresif Siswa di SMKN 4 Mataram. Jurnal Paedagogy, 7(4), 385-392. doi:https://doi.org/10.33394/jp.v7i4.2881

Gunawan, I., \& Wulandari, J. (2017). Pengaruh Teknik Biblioterapi Terhadap Kesadaran Diri Siswa. Jurnal Kependidikan: Jurnal Hasil Penelitian dan Kajian Kepustakaan di Bidang Pendidikan, Pengajaran dan Pembelajaran, 3(1). doi:https://doi.org/10.33394/jk.v3i1.475

Hallen A. (2002). Bimbingan dan Konseling dalam Islam, Jakarta : Ciputat Pers.

Hakim, Soelthon. (2004). Pengelolahan Pelayanan Bimbingan dan Konseling", makalah disajikan pada Diklat Kurikulum Berbasis Kompetensi Bagi Guru Bimbingan dan Konseling SMP Negeri/ Swasta Provinsi Jawa Timur, Malang 29 Nopember s.d 8 Desember 2004.

Hadi, Sutrisno. (2001). Metodologi Research. Yogyakarta: Andi.

Moleong, L. (2004). Metodologi Penelitian Kualitatif. Bandung: Remaja Rosdakarya.

Moerbudi. (2004). Layanan Bimbingan dan Konseling di Sekolah Berbasis Kompetensi. makalah disajikan pada Diklat Kurikulum Berbasis Kompetensi Bagi Guru Bimbingan dan Konseling SMP Negeri/ Swasta Provinsi Jawa Timur, Malang 29 Nopember s.d 8 Desember 2004 .

Nawawi, Hadari. (2005). Metode Penelitian Pendidikan dan Sosial. Yogya : G M University press. 
Prayitno. (2001). Buku Pedoman Bimbingan dan Konseling untuk SMA. Depdiknas Dirjendikdasmen, Jakarta. - (2007) Wawasan Pengembangan Diri Dalam KTSP Melalui Pelayanan Konseling, Depdiknas - Dirjen PMPTK. (2003). Pendekatan Kontekstual (Contextual Teaching and Learning), Depdiknas - Dirjendikdasmen. "Penelitian Tindakan Kelas (Action Research) “, Depdikbud

Pidarta, Made. (2004). Management pendidikan Indonesia. Jakarta : PT Rineka Cipta.

Sudianto, A dan Juntika. N.A. (2005). Manajemen Bimbingan dan Konseling di SMP. Jakarta: PT Grasindo.

Sulistiya, E., \& Jumailiyah, J. (2020). PENGARUH KONSELING REALITA TERHADAP PEMBENTUKAN KEMANDIRIAN PADA SISWA SMPN 2 KURIPAN. Jurnal Paedagogy, 3(2), 52-58. doi:https://doi.org/10.33394/jp.v3i2.3037

Winkel, WS. Dkk. (2006). Bimbingan Dan Konseling Di Institusi Pendidikan. Media Abadi, Yogyakarta.

Zultoni, J., \& Herna Astuti, F. (2020). PENGARUH LAYANAN KONSELING INDIVIDU TERHADAP PENYESUAIAN DIRI SISWA DI SMAN 2 PRINGGARATA. Jurnal Paedagogy, 3(2), 45-51. doi:https://doi.org/10.33394/jp.v3i2.3036 